\title{
Impact of Front Line Demonstration (FLD) on Area and Productivity of Wheat Growers in Jabalpur District of Madhya Pradesh, India
}

\author{
Kalpana Kumari*, V.K. Pyasi and Ashutosh Sharma \\ Department of Extension Education, College of Agriculture, \\ Jawaharlal Nehru Krishi Vishwavidyala, Jabalpur, Madhya Pradesh, India \\ *Corresponding author
}

\section{A B S T R A C T}

\begin{tabular}{|l|}
\hline Ke y w or d s \\
Impact, Area, \\
$\begin{array}{l}\text { Productivity, Wheat } \\
\text { growers, FLD. }\end{array}$ \\
\hline Article Info \\
\hline $\begin{array}{l}\text { Accepted: } \\
17 \text { October } 2017 \\
\text { Available Online: } \\
10 \text { December } 2017\end{array}$ \\
\hline
\end{tabular}

The study on wheat growers within Front line demonstration was conducted in Jabalpur district of Madhya Pradesh state during 2014-15. The number of respondents selected for the study was 100. The data was collected by personal interview method. The study reveals that beneficiaries having small area (up to 2 ha) had absolute change of 0.48 and 44.85 percent relative change in area under wheat crop, having low productivity change (up to $5 \mathrm{q} / \mathrm{ha}$ ) had absolute change of 5.00 and relative change 18.86. The calculated $t$ value for change in area and productivity under wheat between FLD beneficiaries and non-FLD beneficiaries was 8.588 and 19.269 which was found to be significant at 0.01 probability level.

\section{Introduction}

Wheat is the most important source of carbohydrate in a majority of countries. Wheat also contains a diversity of minerals, vitamins and fats (lipids). With a small amount of animal or legume protein added, a wheat-based meal is highly nutritious. Wheat is grown in India over an area of about 266.92 lakh ha. with a production of 721.40 lakh tonnes. The normal National productivity is about $2703 \mathrm{~kg} / \mathrm{ha}$. The major Wheat producing States are Uttar Pradesh, Punjab, Haryana, Madhya Pradesh, Rajasthan, Bihar, Maharashtra, Gujarat, Karnataka, West Bengal, Uttaranchal, Himachal Pradesh and Jammu \& Kashmir. These States contribute about $99.5 \%$ of total Wheat production in the country. Remaining States namely, Jharkhand, Assam, Chhattisgarh, Delhi and other North Eastern States contribute only about $0.5 \%$ of the total Wheat production in the country.

Among food grains, Wheat stands next to Rice, both in area and production. The share of Wheat in total food grain production is around $35.5 \%$ and share in area is about $21.8 \%$ of the total area under food grains.

Front Line Demonstration (FLD) was started in wheat to generate production data and feedback information to various development agencies, which are engaged in dissemination 
of technological advances through researchers to the farmer's fields. For increasing the productivity and improving the economic condition of the farmers, depend upon the level of knowledge and skills of the farmers. The FLD aimed at achieving this twin objective by bringing about the change in knowledge and adoption behavior of farmers. The frontline demonstration is the important mandate of Krishi Vigyan Kendra

\section{Materials and Methods}

In Madhya Pradesh state consist of 49 Krishi Vigyan Kendra operations since 1976 under different organizations like State Agricultural Universities. Out of these, the study was conducted in the Krishi Vigyan Kendra, Jabalpur district of Madhya Pradesh state. This KVK is working under the jurisdiction of JNKVV, Jabalpur. Out of total 7 blocks in the district shahpura block were selected purposively because maximum demonstrations on wheat crop were conducted in this block as compared to other blocks.

A list of villages in which demonstrations on wheat crop were conducted under FLD has been prepared with the help of KVK centre. Out of which 3 villages have been selected for the study on the basis of maximum demonstrations conducted under wheat crop adopted by KVK under FLD.

From selected villages, farmers on whose fields FLD of wheat crops was taken up selected 50 Beneficiaries and 50 Non beneficiaries. Thus, the total 100 wheat growers were considered as respondent for this study. The data were collected personally through pre-tested interview schedule which was prepared on the basis of objectives of the study. Collected data were processed and tabulated by using appropriate statistical tools like percentage, mean, standard deviation and correlation coefficient.

\section{Results and Discussion}

\section{Impact of FLD on area and productivity of wheat growers}

Table 1 shows the absolute change and relative change in area of the beneficiaries after conducting FLD on their field. The data reveals that beneficiaries having small area (up to 2 ha) had absolute change of 0.48 and 44.85 percent relative change in area under wheat crop, while beneficiaries having medium area (2.1 to 4 ha) had 0.84 absolute change and 50.00 percent relative change and for beneficiaries having large area (above 4 ha) had absolute change of 1.1 and 35.48 percent relative change in area under wheat crop. Thus in overall there was 46.15 percent relative change in area under wheat crop through wheat production technology shown in FLD.

Table 2 shows the absolute change and relative change in productivity of the beneficiaries after conducting FLD on their field. The data reveals that beneficiaries having low productivity change (up to $5 \mathrm{q} / \mathrm{ha}$ ) had absolute change of 5.00 and relative change 18.86, while beneficiaries having medium productivity change (5.1 to $10 \mathrm{q} / \mathrm{ha})$ had absolute change of 9.08 and relative change of 18.86 percent and for beneficiaries having high productivity change (above 10 $\mathrm{q} / \mathrm{ha}$ ) had absolute change of 12.25 and 54.41 percent relative change. Thus in overall there was 48.09 percent relative change in productivity of wheat crop through wheat production technology shown in FLD.

Table 3 shows that the calculated $\mathrm{t}$ value for change in area under wheat between FLD beneficiaries and non-FLD beneficiaries was 8.588 which was found to be significant at 0.01 probability level. Thus the earlier stated null hypothesis that there is no difference between the change in area under wheat of the 
FLD beneficiaries and non-FLD beneficiaries is rejected. Hence it can be concluded that there is significant difference between change in area of beneficiaries and non-beneficiaries of FLD.

Table 4 shows that the calculated $\mathrm{t}$ value for change in productivity between FLD beneficiaries and non-FLD beneficiaries was
19.269 which was found to be significant at 0.01 probability level. Thus the earlier stated null hypothesis that there is no difference between the change in productivity of the FLD beneficiaries and non-FLD beneficiaries is rejected. Hence it can be concluded that there is significant difference between change in productivity of beneficiaries and nonbeneficiaries of FLD.

Table.1 Absolute change and relative change in area under wheat crop of FLD beneficiaries

\begin{tabular}{|c|c|c|c|c|}
\hline $\begin{array}{c}\text { S. } \\
\text { No. }\end{array}$ & Categories & Frequency & $\begin{array}{c}\text { Absolute change } \\
\text { (ha) }\end{array}$ & $\begin{array}{c}\text { Relative change } \\
(\%)\end{array}$ \\
\hline 1. & Small (up to 2 ha) & $\begin{array}{c}21 \\
(42.00)\end{array}$ & 0.48 & 44.85 \\
\hline 2. & Medium (2.1 to 4 ha) & $\begin{array}{c}24 \\
(48.00)\end{array}$ & 0.84 & 50.00 \\
\hline 3. & Large (Above 4 ha) & $\begin{array}{c}5 \\
(10.00)\end{array}$ & 1.10 & 35.48 \\
\hline & Overall average & & 0.72 & 46.15 \\
\hline
\end{tabular}

Figures in the parentheses indicate percentage

Table.2 Absolute change and relative change in productivity of FLD beneficiaries

\begin{tabular}{|c|c|c|c|c|}
\hline $\begin{array}{c}\text { S. } \\
\text { No. }\end{array}$ & Categories & Frequency & $\begin{array}{c}\text { Absolute } \\
\text { change } \\
(\mathbf{q} / \mathbf{h a})\end{array}$ & $\begin{array}{c}\text { Relative change } \\
(\boldsymbol{\%})\end{array}$ \\
\hline 1. & Low (up to 5 q/ha) & $\begin{array}{c}2 \\
(4.00)\end{array}$ & 5.00 & 18.86 \\
\hline 2. & Medium(5.1 to 10 q/ha) & $\begin{array}{c}19 \\
(38.00)\end{array}$ & 9.08 & 39.61 \\
\hline 3. & High (above 10 q/ha) & $\begin{array}{c}29 \\
(58.00)\end{array}$ & 12.25 & 54.41 \\
\hline & Overall average & & 10.87 & 48.09 \\
\hline
\end{tabular}

Figures in the parentheses indicates percentage

Table.3 Mean, S.D. and t-value for change in area under wheat between FLD beneficiaries and non-FLD beneficiaries

\begin{tabular}{|c|c|c|c|c|}
\hline S. No. & Beneficiaries & Mean & S.D. & t-value \\
\hline 1. & FLD & 0.72 & 0.309 & \multirow{2}{*}{$8.588^{* *}$} \\
\hline 2. & Non-FLD & 0.27 & 0.196 & \\
\hline
\end{tabular}

$* *=$ significant at 0.01 probability level 
Table.4 Mean, S.D. and t-value for change in productivity of wheat between FLD beneficiaries and non-FLD beneficiaries

\begin{tabular}{|c|c|c|c|c|}
\hline S. No. & Beneficiaries & Mean & S.D. & t-value \\
\hline 1. & FLD & 10.87 & 1.963 & \multirow{2}{*}{$19.269 * *$} \\
\hline 2. & Non-FLD & 3.34 & 1.944 & \\
\hline
\end{tabular}

$* *=$ significant at 0.01 probability level

Table.5 Correlation between Independent variables with area increment of FLD beneficiaries

\begin{tabular}{|c|l|c|}
\hline S. No. & \multicolumn{1}{|c|}{ Independent Variables } & Correlation coefficient (r) \\
\hline 1. & Age & $0.120 \mathrm{NS}$ \\
\hline 2. & Education & $0.344^{*}$ \\
\hline 3. & Family size & $0.144 \mathrm{NS}$ \\
\hline 4. & Land holding & $0.535^{* *}$ \\
\hline 5. & Occupation & $0.285^{*}$ \\
\hline 6. & Area under wheat crop & $0.564^{* *}$ \\
\hline 7. & Economic motivation & $0.071 \mathrm{NS}$ \\
\hline 8. & Risk preference & $0.342^{*}$ \\
\hline 9. & Scientific orientation & $0.078 \mathrm{NS}$ \\
\hline 10. & Extent of knowledge & $0.326^{*}$ \\
\hline 11. & Extent of adoption & $0.313^{*}$ \\
\hline 12. & Social participation & $-0.176 \mathrm{NS}$ \\
\hline 13. & Extension participation & $0.311^{*}$ \\
\hline 14. & Cosmopoliteness & $-0.056 \mathrm{NS}$ \\
\hline 15. & Mass media contact & $0.318^{*}$ \\
\hline
\end{tabular}

$*=$ significant at 0.05 probability level $* *=$ significant at 0.01 probability level NS = Non-significant.

Table.6 Correlation between Independent variables with productivity increment of FLD beneficiaries

\begin{tabular}{|c|l|c|}
\hline S. No. & \multicolumn{1}{|c|}{ Independent Variables } & Correlation coefficient (r) \\
\hline 1. & Age & $-0.146 \mathrm{NS}$ \\
\hline 2. & Education & $0.340^{*}$ \\
\hline 3. & Family size & $0.050 \mathrm{NS}$ \\
\hline 4. & Land holding & $0.292^{*}$ \\
\hline 5. & Occupation & $0.388^{* *}$ \\
\hline 6. & Area under wheat crop & $0.303^{*}$ \\
\hline 7. & Economic motivation & $0.076 \mathrm{NS}$ \\
\hline 8. & Risk preference & $0.307^{*}$ \\
\hline 9. & Scientific orientation & $-0.138 \mathrm{NS}$ \\
\hline 10. & Extent of knowledge & $0.283^{*}$ \\
\hline 11. & Extent of adoption & $0.282^{*}$ \\
\hline 12. & Social participation & $0.019 \mathrm{NS}$ \\
\hline 13. & Extension participation & $0.300^{*}$ \\
\hline 14. & Cosmopoliteness & $-0.238 \mathrm{NS}$ \\
\hline 15. & Mass media contact & $0.342^{*}$ \\
\hline
\end{tabular}

$*=$ significant at 0.05 probability level $* *=$ significant at 0.01 probability level NS = Non-significant. 
To determine the relationship between selected independent variables with the area increment of FLD beneficiaries correlation was workout and presented in Table 5. The finding revealed that out of 15 independent variables only 2 variable i.e. Land holding and area under wheat crop were found to be positive and highly significantly correlated at 0.01 level of probability and education, occupation, risk preference, extent of knowledge, extent of adoption, extension participation and mass media contact were found to be positive and significantly correlated at 0.05 level of probability with the area increment of FLD beneficiaries.

Other variables i.e. Age, family size, economic motivation, scientific orientation, social participation and cosmopoliteness did not indicate any significant relationship with the area increment of FLD beneficiaries. The finding is supported by Nagle (2011) and Verma (2013).

To determine the relationship between selected independent variables with the productivity increment of FLD beneficiaries correlation was workout and presented in Table 6. The finding revealed that out of 15 independent variables only one variable i.e.

Occupation was found to be positive and highly significantly correlated at 0.01 level of probability and education, land holding, area under wheat crop, risk preference, extent of knowledge, extent of adoption, extension participation and mass media contact were found to be positive and significantly correlated at 0.05 level of probability with the productivity increment of FLD beneficiaries.

Other variables i.e. Age, family size, economic motivation, scientific orientation, social participation and cosmopoliteness did not indicate any significant relationship with the productivity increment of FLD beneficiaries. The finding is supported by Nagle (2011) and Verma (2013).

It concluded from the study, the results shows that absolute change and relative change in area and productivity of the beneficiaries after conducting FLD on their field overall there was 46.15 and 48.09 percent relative change in area and productivity under wheat crop through wheat production technology shown in FLD. There is significant difference between change in area of beneficiaries and non-beneficiaries of FLD.

\section{References}

Dayaram, Angad Prasad, B.P. Misra, M. Kumar and G. Kar (2010) Correlates of improved wheat production technology. Indian Res. J. Extn. Edun. 10 (1): 62-64.

Dhakad, V.S. (2006) A study of the impact on knowledge and adoption level of Mustard growers in gird region of Madhya Pradesh M.Sc. (Ag.) thesis (unpublished), JNKVV, Jabalpur

Gautam U.S., Paliwal D. and Kumar Nirmal (2006) "Impact of FLD on soybean Production in improved livelihood of farmers in M.P. An abstract paper 4th National Extn. Edu. Congress on Livelihood security and Extn. System, Perspectives March 9-11, 2007 at JNKVV, Jabalpur p.p. 139-140.

Halakatti, S.V., Gowda D.S.M., Kamaraddi V. and Nadagaudar V.S. (2004) "Impact of participatory Front Line Demonstration in Groundnut in Haveri Distt. of Karnataka, an abstract paper, 2nd National Extn. Edu. Congress May 22-24, 2004; MPUAT, Udaipur p. 107.

Jatav, H.R. (2010) "A study on impact of Front Line Demonstration on scientific temperament of Wheat growers in Indore and Dewas district (M.P.), M.Sc. (Ag.) thesis (unpublished), RVSKVV, Gwalior. 
Khare, Y.R. Shrivastava Akhilesh, Kushwah S.S. and Shrivastava Anshul (2006) "Evaluation of Front Line Demonstration on Mustard: A best tool of Extension System", an abstract paper, International Conference on Social Science Perspective in Agricultural Research and Development, February 15-18, 2006, IARI, New Delhi. p.204

Kirar, B.S. Mahajan S.K. and Nashine R. (2004) Impact of Technology Practices on the Productivity of Soybean in FLD, Ind. Res. J. Ext. Edu. - Vol. 5(1) January 2005. pp. 15-17.

Nagle, M. (2011) Impact of Front Line Demonstrations on scientific temperament of wheat growers in Seoni district (M.P.) M.Sc. thesis (unpublished), JNKVV, Jabalpur.

Prasad, Angad, Dayaram, N.N. Singh and M.K. Singh (2007) Correlates of knowledge of frontline demonstration farmers about wheat production technology. Environment and ecology
25(2): 129-131.

Sharma Y.K. and Mishra S.K. (2007) "Role of FLD in Seed Replacement" FLD on Mustard" An abstract paper 4th National Extn. Edu. Congress on Livelihood security and Extn. System, Perspectives March 9-11, 2007 at JNKVV, Jabalpur p.123.

Singh, A.K. (2009) "A study on impact of oilseed Front Line Demonstrations in Adoption of Production Technology by Farmers in Tikamgarh District (MP)" M.Sc. (Ag.) thesis (unpublished), JNKVV, Jabalpur.

Verma D.P. (2013) A study on Imapact of Front Line Demonstrations on pulses by Krishi Vigyan Kendra, Panna M.P. M.Sc. (Ag.) thesis (unpublished), JNKVV, Jabalpur

Verma, V.K. Wankhede, A.K. Sharma, T.R., and Rai, B.D. (2000) Knowledge and awareness about improved production technology of soybean, Mah. J. Extn Edu. Vol. II \& III No. 2.

\section{How to cite this article:}

Kalpana Kumari, V.K. Pyasi and Ashutosh Sharma. 2017. Impact of Front Line Demonstration (FLD) on Area and Productivity of Wheat Growers in Jabalpur District of Madhya Pradesh, India. Int.J.Curr.Microbiol.App.Sci. 6(12): 2237-2242. doi: https://doi.org/10.20546/ijcmas.2017.612.258 